\title{
The concept of schastie/bakht (happiness) in the Russian and Uzbek phraseology
}

\author{
Svetlana Borisovna Koroleva ${ }^{1 *}$, Oquil Juraqulovich Latipov ${ }^{2}$, and Elena Valerievna \\ Polozhevets $^{3}$ \\ ${ }^{1}$ LUNN: Linguistics University of Nizhny Novgorod, The International Research Laboratory of Basic \\ and Applied Aspects of Cultural Identification, Nizhny Novgorod, Russia \\ ${ }^{2}$ Military Technical Institute of the National Guards of the Republic of Uzbekistan, Department of \\ Foreign Languages, Tashkent, Uzbekistan \\ ${ }^{3}$ Central Russian Institute for the Humanities and Technology, Department of Psychology and \\ Pedagogy, Obninsk, Russia
}

\begin{abstract}
The article considers the concept of Schastie/Bakht (Happiness) in the Russian and Uzbek linguistic cultures as one of the most important universal concepts with a national component. On the one hand, the study is conditioned by the interest of modern contrastive linguistics in the comparative research of concepts with a national component. On the other hand, it continues scientific works concerned with the concept of Schastie in the Russian linguistic culture and the concept of Bakht in the Uzbek linguistic culture. The novelty of this study is determined by the fact that this concept is compared for the first time using set phrases of two languages and based on an analytical review of the relevant sources. The article aims at determining common and different components for the Uzbek and Russian linguistic cultures with regard to the Happiness concept (according to the data obtained from the analysis of the above-mentioned material). The article presents the results of an analytical review of studies on the concept of Schastie in the Russian linguistic culture and the concept of Bakht in the Uzbek linguistic culture, as well as contrastive analysis of phraseological units related to the verbalization of these concepts. To analyze and compare idioms of two unrelated languages (Russian and Uzbek) and ways of verbalizing the concept, the authors used the method of linguistic and cultural description supplemented by the component analysis of lexemes and the comparative method. As a result, general and specific meanings for the words "schastie" and "bakht" were identified, as well as general and specific components of the Happiness concept.
\end{abstract}

Keywords: concept, verbalization forms, non-equivalent vocabulary, figures of speech, cultural linguistics, Russian language, Uzbek language.

\section{Introduction}

Happiness is a universal concept. It is an important element of the folklore of various peoples [1], a crucial theme of literary texts and paintings [2], the subject of reflections of thinkers

*Corresponding author: svetlakor0808@gmail.com. 
and philosophers [3-5], the research object of various sciences [6, 7]. It is fixed in the system of lexemes, proverbs, sayings and set phrases united by the corresponding component of the meaning. Scholars have been studying the concept of Schastie in various forms of its Russian verbalization. There are many relevant studies in the Uzbek language. Summarizing the results of linguistic research available in relation to the Russian concept [8-11], we should note the most developed scientific ideas about its content in phraseology [8] and the Russian classical literature [9]. The Russian phraseology embraces such meanings and components of the concept of Schastie as "joy" ("to be in seventh heaven from happiness"), "hard work" (necessary to achieve happiness: "to forge one's happiness"); "love and harmony" ("love and harmony is happiness"); "inconstancy" and "accident" ("it is easy to find happiness but it is even easier to lose it"; "happiness is a free bird, wherever it wants, it settles there", "happiness and misfortune are close neighbors"); "falsity, deceit" ("do not believe in happiness at all"; "do not believe in happiness, but do not be afraid of trouble"); "personal fate" ("to each their own happiness"; "happiness is not in one's will but rather in one's fate").

The Russian classical literature offers new components of the concept: "happiness as a valuable experience" ("They say that misfortune is a good school, maybe. Yes, true. But happiness is the best university" by A.S. Pushkin); "sacrificial service" as an element of personal happiness ("There is only one undoubted happiness in life - to live for another" by N.G. Chernyshevsky; "The desire to serve the common good must without fail be a requisite of the soul, a necessity for personal happiness" by A.P. Chekhov); "consciousness in fostering a sense of happiness" ("The secret of happiness is not always doing what you want, but always wanting what you do" by L.N. Tolstoy).

As for studies of the Bakht concept in the Uzbek language [12, 13], they mainly relate to set phrases and can be described by the following system of components: "joy" ("bakht kulgu bor uyga kirar"/happiness comes to a joyful house); "labor" (something that can bring happiness: "meunat - bakht keltirar"/labor brings happiness); "impermanence" ("bakht kam, bakhtsizlik kam zhuft buladi"/happiness and unhappiness come in pairs); "luck" ("bakht omad keltiradi, bakhtsizlik kulfat keltiradi"/happiness brings good luck, misfortune brings trouble); "the importance of children's happiness for parents" ("farzand bakhti - ona takhti, farzand kamoli - ot zhamoli"/the happiness of a child is the happiness of parents); "persistence" and "striving" (in search of happiness: "bakht tsochganga emas, tsuvganga tuttsich berar"/happiness is caught by the one who runs after it, not the one who avoids it); "insignificance" (happiness as good luck: "bakhtingga ishonma, barmogingga ishon"/do not rely on happiness, but rely on yourself); "knowledge" ("bilim - bakht kelti-rar"/knowledge brings happiness); "loyalty" ("audi borning bakhti bor"/a faithful person is happy); "concordance, union and friendship" ("bakht tsaerda - ittifotslikda"/happiness lies in the union; "bakht garovi - dustlik"/friendship is a guarantee of happiness); "fate" ("bakht sanditsda, kaliti - osmonda"/happiness is in the chest, and the key is in heaven).

\section{Methods}

There are no special contrastive linguistic studies of the Schastie/Bakht concept in the Russian and Uzbek languages, therefore this article tries to summarize studies based on phraseology, explanatory dictionaries and comparative-analytical review of the results available in relation to the concept of Schastie in the Russian linguistic culture and the concept of Bakht in the Uzbek linguistic culture. To analyze and compare idioms of two unrelated languages (Russian and Uzbek) and ways of verbalizing the concept, we used the method of linguistic and cultural description supplemented by the component analysis of lexemes. As a result, general scientific methods of analysis and comparison were applied to generalize the results available in various studies of the concept of Schastie/Bakht. 


\section{Results and discussion}

Let us turn to the meanings of the basic words for the above-mentioned concept in the Russian and Uzbek languages, respectively. According to the Large Explanatory Dictionary of the Russian Language, the "schastie" word has four meanings: "1. A state of supreme satisfaction with life, a feeling of deep contentment and joy experienced by somebody; external manifestation of this feeling. $<\ldots>2$. Success, luck. $<\ldots>3$. Colloquial. Fate, fortune, destiny. $<\ldots>4$. As a predicate (with a subordinate clause, with an infinitive). It is good that. $<\ldots>$ ". [14].

The Explanatory Dictionary of the Uzbek language defines "bakht" as follows: " 1 . Kishining y̆z faoliyati natijalaridan, xayotda қy̆lga kiritgan yutuқlaridan tula қопіқіshi, yashash tarzidan mamnunligi, muayyan maқsadga etgani, orzu-umidining ushalishi sifatida namoen bŭladigan manavij-axlokij tuşuncha/A spiritual and moral concept that reflects the complete satisfaction of a person with the results of their activities, life achievements, lifestyle, the realization of certain goals and desires; 2. Saodat/Bliss; 3. Omad, tole; іқbol/Luck, fortune, well-being [15: 213].

As we can see from the meanings of the key words denoting this universal concept in the Russian and Uzbek languages and noted in modern dictionaries, the concept in the two cultures is by no means identical. It coincides in such meanings as "the (highest) satisfaction" and "luck" and does not coincide in the other meanings or their components: "fate, destiny" and "good, successful" (typical of the Russian word "schastie"), "bliss, well-being" (common only to the Uzbek word "bakht"), "the results of one's activities, achievements, the realization of goals and desires" (components of the meaning are highlighted in the first meaning of the word "bakht" in the dictionary of the Uzbek language).

These data are not accurate. In conformity with the arguments provided by S.G. Vorkacheva (in particular, the presence of the word "blazhenstvo" (bliss) in the Russian language as a semantic doublet of the word "schastie" (happiness) [11], we can claim that "bliss" is a meaning equally significant for the Uzbek concept Bakht and the Russian concept Schastie.

While comparing the above-mentioned studies of set phrases, we have clarified the following facts: in addition to the general meaning of "joy", the Russian and Uzbek phraseology is united by such common components of the Schastie/Bakht concept as "labor", "consent", "inconstancy" and "fate, destiny". At the same time, the Uzbek phraseology does not contain the meanings of "falsity", "deceit", "individuality" and "love" typical of the Russian phraseology. In the latter, such significant Uzbek components as "friendship", "loyalty", "happiness of children" and "knowledge" are not expressed.

These data show that in the case of comparing the meanings of "schastie" and "bakht" in modern Russian and Uzbek, one should speak not of complete, but of their partial equivalence (in terms of V.G. Kostomarov and E.M. Vereshchagin [16]). In this regard, the Schastie/Bakht concept is a national component of the universal concept. To clarify the specifics of this national component in relation to the Russian and Uzbek languages, it seems necessary to compare the figures of speech that verbalize the concept and actualize, respectively, the words "schastie" and "bakht".

The concept of Schastie/Bakht is verbalized in several proverbs and clichés that are very close in meaning:

"Ne rodis krasivym, a rodis schastlivym" - "xusning bulguncha, bakhting bulsin" "Better be born lucky than rich" (general opposition: richness - happiness);

"Ne byvat by schastyu, da neschaste pomoglo" - "yomonsiz yashi bulmas, yomonsiz yomon bulmas" - "There would be no fortune, but misfortune helped" (general logic of comparison: a small misfortune can bring great happiness); 


\begin{abstract}
"Schastie ulybnulos" - "bakhti kulmoқ (yoki ochilmoқ)" - "Happiness is on one's side" (common semantic components are "chance" and "luck");

"Bakhtdan sinab kordim" - "to try one's luck" (the general semantic component is "persistent striving");
\end{abstract}

"Bakhti ochilmok" - "to find happiness" (in marriage, in family) (the general idea of family happiness as a basic component of personal happiness);

"Bakhti ketdi" - "happiness leaves someone" (common semantic components are "inconstancy" and "loss");

"Mehnat - bakht keltirar" - "happiness and work live side by side" (general association "happiness - work").

It is worth mentioning that some Uzbek figures of speech have no equivalents in Russian:

"El boқssa, bakhting kular, el boқ̧masa, takhting kular" - literally: "if you are respected by people, you will surely have a good deal of luck, your throne will collapse if people turn away from you";

"Bakht kushi (bakhti xumoyun) boshiga ky̆ndi” - literally: "a bird of happiness sat down on one's head";

"Bakht қushini кy̆lga kiritmoқ" - literally: "to grab the bird of happiness";

"Ota-ona farzandiga takht yaratadi-yu, bakht yarat olmaidi" - literally: "parents give their children a dowry (wealth), but happiness is beyond their powers".

The "bakht" root is a component of the following male and female names: "Bakhtiyor" (as a kind of well-wishing - let luck and happiness accompany the one who bears this name), "Bakhtigul" (literally: "a flower of happiness") and "Bakhtinur" (literally: "illuminated by happiness"). This tradition has no parallels in the Russian language.

The same can be said about Russian phraseology. Spiritual and moral set phrases like "Happy is he whose conscience is calm"; "Happy is he who lives without sins"; "Happy is he who does not drink wine"; "Where there is truth, there is happiness" do not have analogs in the Uzbek language.

\title{
4 Conclusion
}

Summarizing the study results, we can provide the following statements: the abovementioned universal concept is not identical in the Uzbek and Russian linguistic cultures. The concepts of Schastie and Bakht coincide in such basic components (meanings) as "the (highest) satisfaction", "well-being", "luck", "fate, destiny", as well as in such peripheral components as "labor", "consent" and "impermanence". These semes indicate the path to happiness (work, harmony) or an important characteristic of happiness (impermanence).

There are associations of stable power with the respect of people, happiness with a mythological bird, an emphasis on the connection between children and parents, including the ability of parents to contribute to the happiness of their child through the choice of a name, as well as associations of happiness with friendship, loyalty and knowledge. Of course, all these components express the national specifics of the universal concept of Schastie/Bakht in the Uzbek linguistic culture.

According to this study, the national specifics of the concept of Schastie in the Russian linguistic culture embraces the associations of happiness with the truth, a clear conscience and a righteous way of life, including those components that were highlighted in the comparative-analytical review of available works: "falsity, deceit", "individuality" and "love". 


\section{References}

1. J. Phillips, J. De Freitas, C. Mott, J. Gruber, J. Knobe, Journal of Experimental Psychology General, 146(2), 165-181 (2017). https://doi.org/10.1037/xge0000252

2. L. Yang, L.A. Shumikhina, KnE Social Sciences, 4(5), 115-118 (2020). https://doi.org/10.18502/kss.v4i5.6528

3. J. Miller, Social Research, 77(2), 595-624 (2010)

4. A. Hills, History of Philosophy Quarterly, 23(3), 243-261 (2006)

5. D.M. Haybron, Journal of Happiness Studies, 1(2), 207-225 (2000). https://doi.org/10.1023/A:1010075527517.

6. Sh. Oishi, J. Graham, S. Kesebir, I. Costa Galinha, Personality and Social Psychology Bulletin, 39(5), 559-577 (2013). https://doi.org/10.1177/0146167213480042

7. J. Phillips, Emotion Review, 3(3), 320-322 (2011). https://doi.org/10.1177/1754073911402385.

8. A.M. Cherkashina, Vestnik Taganrogskogo Gosudarstvennogo Pedagogicheskogo Instituta [Bulletin of Taganrog State Pedagogical Institute], 2, 38-43 (2016)

9. S.V. Khamidullina, Nauchno-Metodicheskii Elektronnyi Zhurnal "Kontsept", 3, 371375 (2013)

10. N.A. Bozhenkova, Yu.V. Tyulyukina, Kontsept "Schaste" v yazykovoi kartine mira nositelya russkogo yazyka: leksikograficheskii aspekt [The concept of "happiness" in the linguistic worldview of the Russian language: lexicographical aspect], in Clavyanskaya kultura: istoki, traditsii, vzaimodeistvie. XX kirillo-mefodievskie chteniya. Proceedings of the International scientific conference, 70-73 (Institut russkogo yazyka im. A.S. Pushkina, Moscow, 2019)

11. S.G. Vorkachev, Yazyk, Kommunikatsiya i Sotsialnaya Sreda, 2, 4-18 (2002)

12. T.K. Mardiev, Khorizhii Filologiya, 2, 36-43 (2016)

13. N.A. Tukhtakhuzhaeva, Vestnik ChelGU. Filologiya. Iskusstvovedenie, 28(59), 112 $115(2011)$

14. S.A. Kuznetsov (Ed.), Schaste [Happiness], in The Large Explanatory Dictionary of the Russian Language (Saint Petersburg: Norint, 2014)

15. E. Begmatov et al. (Eds.), ǓzBek tilining izohli luojati : 5 zildli : 80000 dan ortiq sŭz va sŭz sirikmasi [Explanatory dictionary of the Uzbek language: 5 years: more than 80,000 words and phrases], Volume 1 (State Scientific Publishing House "National Encyclopedia of Uzbekistan", Tashkent, 2006)

16. E.M.Vereshchagin, V.G. Kostomarov, Yazyk i kultura. Lingvostranovedenie v prepodavanii russkogo yazyka kak inostrannogo [Language and culture. Cultural studies in teaching Russian as a foreign language] (Moscow State University Publishing House, Russkii yazyk, Moscow, 1976) 